\title{
Comparative Studies on the Effect of Adjuvants with Urea to Reduce the Overwintering Inoculum of Venturia inaequalis
}

\author{
Janna Beckerman ${ }^{\dagger}$ and Chelsi Abbott \\ Department of Botany and Plant Pathology, Purdue University, West Lafayette, IN 47907
}

\begin{abstract}
A 2-year study on the use of organic and conventional adjuvants alone, or mixed with urea, was conducted for management of overwintering inoculum of the apple scab pathogen, Venturia inaequalis. Select adjuvants (LI 700, Bond Max, Latron B-1956, and Organic Wet Betty [OWB]) have the potential to hasten urea-driven leaf litter decomposition and reduce $V$. inaequalis overwintering inoculum comparable to urea, and that one organic surfactant could perform the same level of leaf decomposition as urea. Combinations of adjuvants with urea significantly improved leaf litter degradation compared with urea alone, concomitant with

reducing the number of pseudothecia present and pseudothecium fertility. We demonstrate that the combination of urea with Bond Max or OWB reduced pseudothecia fertility and ascospore production to less than $5 \%$ in the remaining pseudothecia, a significantly greater reduction than with urea alone. These results suggest that conventional growers combine urea with Bond Max or OWB to more effectively reduce overwintering inoculum, and that the adjuvant OWB can provide organic growers with comparable performance to urea used in conventional orchards for improved sanitation.
\end{abstract}

Apple scab, caused by the fungus Venturia inaequalis (Cke.) Wint., is one of the most important diseases of apple (Malus domestica) in regions that experience cool, wet springs (MacHardy et al. 2001; Sutton 1990). Both organic and conventional growers rely heavily on fungicides for disease management, often applying 20 or more applications of fungicide per season on highly susceptible varieties (Beckerman et al. 2015; Beresford et al. 2000). For conventional growers, fungicides within several Fungicide Resistance Action Committee groups are registered for controlling apple scab, including dodine, methyl benzimidazole carbamates, demethylation inhibitors, quinone outside inhibitors, and succinate dehydrogenase inhibitors (Jones and Walker 1976; Köller et al. 1997, 2004; McKay et al. 2011; Szkolnik and Gilpatrick 1969). However, the extensive use of many of these fungicides has resulted in the development of resistant strains of $V$. inaequalis within a couple years of their respective releases (Köller et al. 2004), and even strains with multiple resistances to different fungicides (Chapman et al. 2011). Inadequate control has led to the greater reliance on older protectant fungicides, such as captan, that have low risk of developing pathogen resistance (Abbott and Beckerman 2018; Beckerman et al. 2015).

For organic apple disease management, growers use resistant varieties and many of the same cultural practices conventional growers use; however, the application of approved copper-based fungicides, lime-sulfur, or sulfur are used for disease management, despite issues of phytotoxicity inherent with using these products (Beckerman 2008). Furthermore, recent rules have reduced the amount of copper permitted in organic farming in the European Union (Council Regulation [EEC] No. 2092/91). For both conventional and organic growers, changing climate conditions, coupled with changing pesticide regulations, have resulted in an increasing number of disease management failures, and restrictions in the amount of fungicides allowed to be applied per year have made the addition of cultural

${ }^{\dagger}$ Corresponding author: Janna Beckerman; E-mail: jbeckerm@ @urdue.edu

Funding: Funding was provided by the United States Department of Agriculture, National Institute of Food and Agriculture (USDA-NIFA) grant no. 2014-09534.

*The $\boldsymbol{e}$-Xtra logo stands for "electronic extra" and indicates that one supplementary figure is published online.

Accepted for publication 17 September 2018.

C 2018 The American Phytopathological Society practices such as sanitation necessary for adequate disease management (Beckerman et al. 2015).

In organic and conventional apple production, the use of pesticides, resistant varieties, and cultural practices form the foundation of successful disease management, but the issue of overwintering inoculum persists. Sanitation focuses on removing the overwintering inoculum of $V$. inaequalis and has been shown to reduce both the initial disease pressure and the amount of chemicals needed for control during the growing season (Meszka and Bielenin 2006; Sutton et al. 2000). Any reduction of inoculum present in the spring could significantly reduce the disease incidence in the orchard during the growing season (Rosenberger and Cox 2012). This reduction could delay the epidemic of apple scab and potentially result in fewer applications of pesticide needed to successfully manage the disease (Gadoury and MacHardy 1986). Because the pathogen overwinters in leaves on the orchard floor, practices that remove the leaf litter by shredding, chemical treatments, or urea applications are essential for good sanitation (Sutton et al. 2000; Vincent et al. 2004).

Shredding the leaf litter can reduce scab incidence by $90 \%$ in a controlled environment (Sutton et al. 2000). In actuality, reduction of inoculum from shredding or removal of the leaf litter may range from 50 to $65 \%$ owing the variable topography and obstructions in orchards, in addition to this practice being time consuming and difficult (Vincent et al. 2004). In Belgium, where a prototype machine was built and utilized for leaf shredding, scab incidence was reduced by $75 \%$ on shoot leaves (Creemers et al. 2002).

Alternatively, spray applications to decrease the leaf litter may be an effective substitute to shredding and removal (Vincent et al. 2004). Historically used chemical compounds, such as mercury, have shown promise in reducing primary inoculum and the number of fungicide treatments needed during the growing season (Burchill 1968; Goldsworthy et al. 1949; Kadow and Hopperstead 1941; Keitt 1930), but owing to their harmful effects to the environment and nontarget organisms, many of these chemicals are no longer used (Sutton et al. 2000). This led to research on other methods such as the use of urea or biological control (Rosenberger 2003; Sutton et al. 2000). Biological control using fungi that are antagonistic to ascospore production has shown promise, but field efficacy, registration, commercialization, and costs have been major obstacles in the practicality of these products (Rosenberger 2003). Thus, urea, with its relatively low application costs and accessibility to growers, is a more suitable product (Vincent et al. 2004).

Urea is a synthetic nitrogen fertilizer that promotes litter decomposition and inhibits $V$. inaequalis pseudothecia development by maintaining high nitrogen content in the leaves (Beresford et al. 2000; 
Sutton et al. 2000). Because urea is a synthetic compound, organic growers are not permitted to use it in their management programs in the United States or the European Union (Appendix II, R EEC/ 2092/91). This limits apple scab sanitation options exclusively to removal or shredding the leaf litter (Gomez et al. 2007), practices which are often time consuming and difficult to implement (Vincent et al. 2004). As a consequence, organic orchards often have poor primary scab management, resulting in epidemics (Holb et al. 2005). This high disease pressure may ultimately reduce the efficacy of summer management techniques, leading to management failures and consequently causing major economic loss (Jamar 2011).

In conventional orchards, where urea is permitted, treatments may be applied after harvest but before leaf fall (Beresford et al. 2000). Applying urea before leaf fall can have adverse effects to the health of the tree, because additional nitrogen may prolong tree growth, ultimately delaying tree dormancy (Rosenberger 1996; Schupp et al. 2001) and increasing the likelihood of cold damage to buds, reducing yield the following season (Schupp et al. 2001; Wood and Beresford 2000). Alternatively, urea can be applied to the orchard floor after leaves have abscised from the tree (Beresford et al. 2000). Issues with ground applications include inadequate coverage and reduced efficacy if the ground freezes soon after the treatment is applied, preventing any effect on the inoculum (Ciecierski et al. 1995; Mac an tSaoir et al. 2010; Rosenberger 1996).

These factors highlight limitations in primary inoculum management of apple scab in both organic and conventionally managed orchards. Therefore, research that explores new compounds that can be used in organic orchards and that focuses on improving ground applications of urea is needed, particularly on those compounds that increase the coverage and penetration of urea into the leaf litter. One potential solution for improving or potentially substituting for urea applications involves utilizing adjuvants.

Adjuvants are "materials that are added to a tank mix to aid or modify the action of an agrichemical, or physical characteristics of the mixture" (ASTM 1999). Adjuvants have been found to increase the spread, retention, penetration, and overall spray efficiency of materials being applied to plant surfaces (Abbott and Beckerman 2018; Gent et al. 2003; Percich and Nickelson 1982; Steurbaut 1993; Thompson et al. 1996). We hypothesize that the addition of adjuvants may improve urea-driven decomposition of the leaves and further reduce primary inoculum of $V$. inaequalis. To date, no studies have explored the effect of adjuvants in combination with urea on ureadriven leaf litter decomposition and inoculum reduction. Additionally, it has yet to be explored if organic adjuvants may be comparable alternatives to urea for use in organic orchards. This demonstrates the need to identify if the incorporation of adjuvants with urea or adjuvants alone could reduce leaf litter and primary inoculum of $V$. inaequalis.

\section{Materials and Methods}

Inoculum. Intact, scab-infected leaves were collected from apple trees located at Meigs Farm, Throckmorton Purdue Agricultural Center (Lafayette, IN), in the fall for all years in this trial. In the fall of 2014 , a study was conducted to test the effect of adjuvants when combined with urea to reduce the primary inoculum of $V$. inaequalis using naturally infected McIntosh leaves. Naturally infected McIntosh
(M. domestica 'McIntosh') and Gala (M. domestica 'Gala') leaves were used for this study in 2015 .

Experimental design. Treatment blocks were set up in a randomized complete block design in a 5-year-old block of McIntosh apple trees on B9 rootstock planted in Toronto-Millbrook soil (soil pH: 6.7). McIntosh trees were planted $3 \mathrm{~m}$ apart with $5 \mathrm{~m}$ between each row in a 0.2 -ha field containing 80 trees. In the 2014 trial, the treatment blocks were arranged in a randomized complete block design of 10 treatments with four replications containing 10 leaves each, with a total of 400 leaves. On 13 October 2013, leaves were immersed in their respective treatments for $10 \mathrm{~s}$ and were placed under a $0.2 \times$ $0.2-\mathrm{m}$ screen wire mesh for overwintering on the orchard floor. Data from this study were acquired and analyzed in the spring of 2014 and henceforth will be referred to as the 2014 trial. At the time of treatment application in 2013 , the temperature was $20^{\circ} \mathrm{C}$; precipitation was recorded only on 24 October $(0.28 \mathrm{~cm})$. In the fall of 2014 , a larger study was conducted in the same field plot. The treatment blocks were expanded to include two rows of the 5-year-old McIntosh apple trees on B9 or EMLA 26 rootstocks. For this trial, the treatment blocks were arranged in a randomized complete block design of 10 treatments with four replications each containing 50 leaves. This design was applied to both McIntosh and Gala leaves, with a total of 2,000 McIntosh leaves and 2,000 Gala leaves, including nontreated controls. At the time of treatment application, on 23 October 2014 , the temperature was $17^{\circ} \mathrm{C}$, and after the trial began, rain was recorded on 24 October $(0.05 \mathrm{~cm}), 28$ October $(0.84 \mathrm{~cm})$, and 31 October $(0.51 \mathrm{~cm})$ (Supplementary Fig. 1). Data from this study were acquired and analyzed in the spring of 2015 and henceforth will be referred to as the 2015 trial.

Sanitation treatments. Adjuvants used in this study are listed in Table 1; these products were tested for their ability to improve ureadriven leaf litter decomposition of scab-infected leaves and reduction of $V$. inaequalis pseudothecia. Concentrations of all adjuvants were based on recommended rates on commercial product labels. In congruence with the literature, a 5\% urea (urea, granular 46-0-0) solution was used (Sutton et al. 2000). In the 2014 trial, on 23 October 2014, 400 scab-infected McIntosh leaves were collected after harvest and were immersed in their respective treatments for $10 \mathrm{~s}$ and then placed under wire mesh for overwintering on the orchard floor. In the 2015 trial, 2,000 scab-infected McIntosh leaves and 2,000 scab-infected Gala leaves were collected after harvest, and all scab-infected leaves were immersed in their respective treatments for $10 \mathrm{~s}$ and then placed under wire mesh for overwintering on the orchard floor. For both years, an additional 100 nontreated leaves were overwintered similarly to serve as a check group.

Leaf litter quantification. For both years, all overwintered leaves were collected in the spring (April to May) and scanned on an Epson Perfection V37 desktop scanner at 600 dpi (Epson America, Long Beach, CA) connected to a personal computer. ImageJ, a digital image assessment program (Schneider et al. 2012) was used to quantify leaf litter area associated with each replication of each treatment. In the 2014 trial, the degradation of leaf litter was determined by comparing the area of all leaves recovered from the wire mesh after overwintering. In the 2015 trial, leaves were scanned before and after overwintering on the orchard floor to analyze total leaf percent area lost.

Table 1. List of materials used in this study to reduce overwintering $V$. inaequalis inoculum

\begin{tabular}{llcll}
\hline Trade name & \multicolumn{1}{c}{ Active ingredient } & $\begin{array}{c}\text { Concentration } \\
\text { per 379 liters }\end{array}$ & Manufacturer & Classification \\
\hline $\begin{array}{llcl}\text { Urea, granular 46-0-0 } \\
\text { LI 700 }\end{array}$ & $\begin{array}{l}\text { Nitrogen } \\
\text { Phosphatidylcholine, methylacetic acid, and } \\
\text { alkyl polyoxyethylene ether }\end{array}$ & $\begin{array}{c}20 \mathrm{~kg} \\
0.3 \text { liter }\end{array}$ & $\begin{array}{l}\text { Agrium } \\
\text { Loveland Industries }\end{array}$ & $\begin{array}{l}\text { Fertilizer } \\
\text { Acidifier, penetrant, drift reduction }\end{array}$ \\
$\begin{array}{l}\text { Alcohol ethoxylate, 1,2-propanediol, and } \\
\text { Bond Max }\end{array}$ & 0.4 liter & Loveland Industries & Spreader-sticker, deposition aid \\
$\begin{array}{l}\text { Latron B-1956 } \\
\begin{array}{l}\text { Organic Wet Betty } \\
\text { (OWB) }\end{array}\end{array}$ & $\begin{array}{l}\text { Modified phthalic glycerol alkyd resin } \\
\text { Yucca extract, saponin }\end{array}$ & 0.3 liter \\
\end{tabular}


Assessing pseudothecia and ascospore development. For the 2014 trial, assessment of pseudothecia and ascospore development began when the first ascospore discharge was microscopically observed from nontreated check leaves. Total number of pseudothecia present on leaves in all treatments was counted and recorded from each replicate. Throughout May 2014, eight randomly selected pseudothecia from each replicate, totaling 32 pseudothecia per treatment, were removed, crushed on glass microscope slides, and inspected for ascospore development. The number of pseudothecia selected per treatment was chosen to eliminate possible treatment bias because one treatment only had 32 pseudothecia present. For the 2015 trial, when $50 \%$ of pseudothecia in the nontreated check group were producing mature ascospores (9 April), all leaves were collected and stored at $4{ }^{\circ} \mathrm{C}$. Collection differed from the 2014 trial owing to the larger number of sampled leaves in the 2015 trial. In the 2015 trial, 25 pseudothecia from each of the four replicates were arbitrarily selected for the asci/ascospore development ratings. Total number of pseudothecia, asci/ascospore development, and consequently percentage of fertile pseudothecia were assessed similar to the 2014 trial.

Statistical analyses. In both 2014 and 2015 trials, leaf area data were averaged within treatments and analyzed with a one-way ANOVA using a generalized linear model procedure (PROC GLM) in SAS version 9.3 (SAS Institute, Cary, NC). Means were separated according to Fisher's protected least significant difference (LSD) test at $P=0.05$ using SAS version 9.3. Total pseudothecia data were averaged within means, subjected to $\log$ transformation $(\log x+$ 1), and analyzed with a one-way ANOVA using a generalized linear model procedure (PROC GLM) in SAS version 9.3. Means were separated using a Fisher's protected LSD test at $P=0.05$ using SAS version 9.3.

\section{Results}

Leaf decomposition. Scab pressure was high for both years, and all leaves used in this study had $20 \%$ scab severity or greater. Visual observation, measuring and comparing the amount of material remaining $(x)$, suggested that select adjuvants and adjuvants + urea enhanced leaf litter decomposition (Fig. 1). In the trial conducted from 2014, the nontreated control had approximately $287 \mathrm{~cm}^{2}$ of leaf tissue remaining, compared with $86 \mathrm{~cm}^{2}$ of tissue remaining for the urea treatment. Owing to the variability in the amount of remaining material, all treatments resulted in a significant reduction in leaf litter compared with the nontreated control, and all treatments of surfactants plus urea were not significantly different from leaf litter reductions compared with urea alone (Fig. 2A), even though these reductions resulted in remaining leaf tissue ranging from a high of $64 \mathrm{~cm}^{2}$ with Latron B-1956 + urea to a low of $25 \mathrm{~cm}^{2}$ with Organic Wet Betty (OWB) + urea (Figs. 1 and 2A). With the exception of Latron B-1956, all adjuvants reduced the leaf litter comparable to the urea control (Fig. 2A).

In 2015, two cultivars, McIntosh and Gala, were used, and methodology was changed to measure differences between the amounts of leaf litter lost $(1-x)$, instead of comparing the amounts of leaf litter remaining $(x)$. Leaf litter decomposition did not differ significantly between cultivars. For McIntosh, adjuvants alone performed as well as urea at driving leaf litter decomposition (Fig. 3A). Combining urea with the adjuvants LI 700 or OWB resulted in significantly higher levels of decomposition compared with urea alone, with the control losing less than half of its leaf area, compared with urea $(62.2 \%), \mathrm{LI}$ $700+$ urea $(77.5 \%)$, or OWB + urea $(85.5 \%)$ (Fig. 3A). For Gala leaves, all adjuvants except Latron B-1956 reduced the leaf litter as well as urea (Fig. 3B). When combined, LI $700+$ urea (77.2\%), Bond Max + urea $(77.8 \%)$, and OWB + urea $(77.8 \%)$ significantly reduced the leaf litter compared with the urea control (61\%) (Fig. 3B).

Pseudothecia development and fertility. In the 2014 trial, all treatments, with and without urea, significantly reduced pseudothecia development compared with the nontreated control, from an average of 145 pseudothecia to 5. Only LI 700 alone was comparable to urea in reducing pseudothecia numbers (an average of 15 compared with 5) (Fig. 2B). The combinations of any adjuvants with urea improved performance and reduced the number of pseudothecia as good or better than urea alone (Fig. 2B).

When examining the fertility of the pseudothecia per treatment in the 2014 trial, we found all treatments significantly reduced the number of fertile pseudothecia compared with the nontreated control

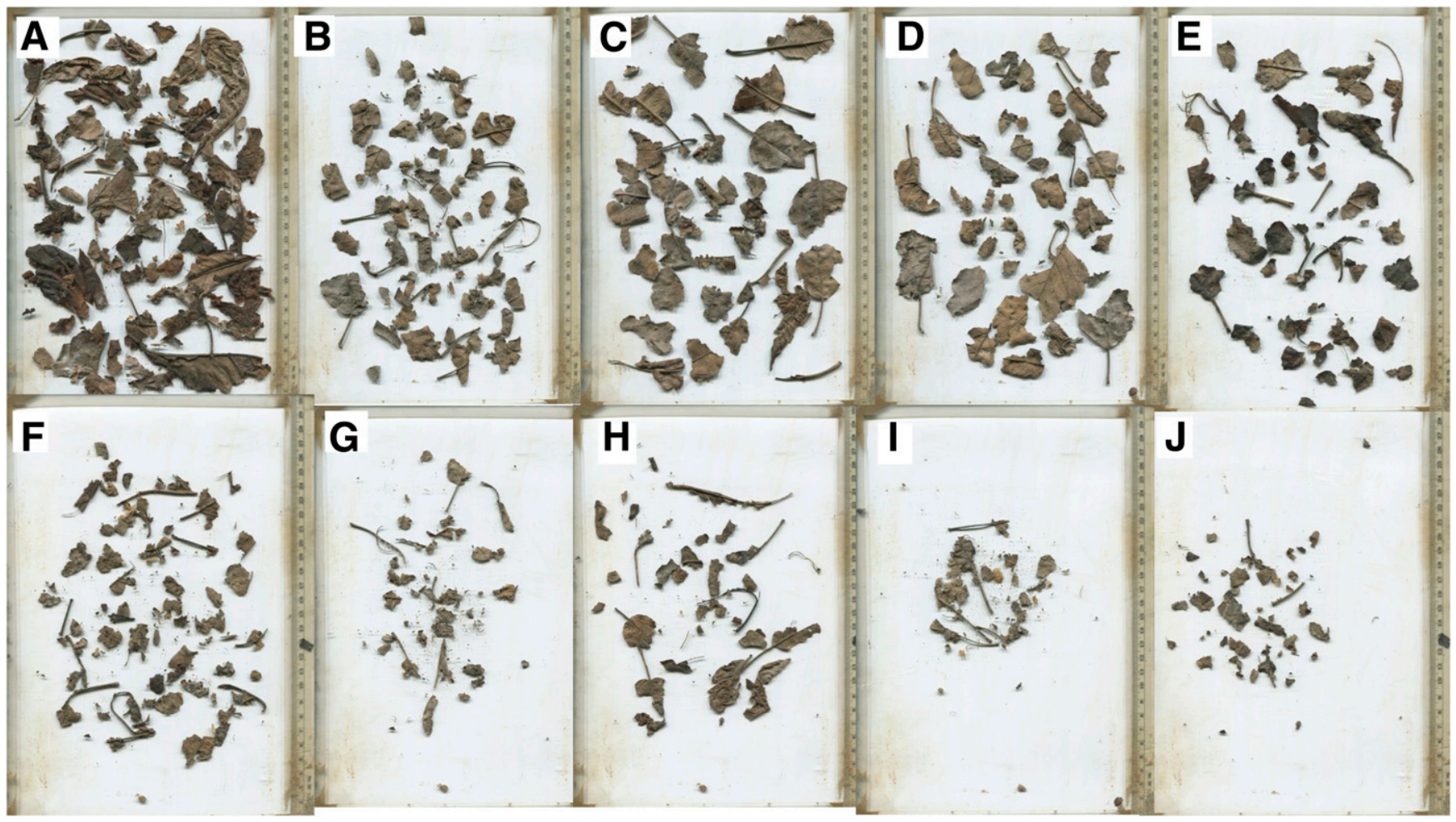

Fig. 1. Representative images showing the leaf litter degradation of 40 leaves per treatment in response to adjuvant and urea treatments in 2014. Treatments: A, water; B, LI 700; C, Bond Max; D, Latron B-1956; E, Organic Wet Betty (OWB); F, urea; G, LI 700 + urea; H, Bond Max + urea; I, Latron B-1956 + urea; and J, OWB + urea. 
(99.2). Urea (72.0), LI 700 (69.8), Bond Max (81.0), Latron B-1956 (85.8), and OWB (69.9) all performed as well as urea. When urea was combined with LI 700, Bond Max, or OWB, a lower number of fertile pseudothecia was observed compared with urea alone (Fig. 2C). When Bond Max or OWB were combined with urea, asci failed to develop ( $0 \%$ fertile pseudothecia; Figs. $2 \mathrm{C}$ and 4$)$, and no ascospores were observed.
In the 2015 trial, we observed similar results for both McIntosh and Gala cultivars, because urea reduced the number of pseudothecia produced (114 for the control versus 44 for urea), and urea with adjuvants further reduced the number of pseudothecia observed (Fig. 3C and D). For McIntosh, only Latron B-1956 (with an average of 72) reduced the number of pseudothecia as well as urea (average of 44) (Fig. 3C). LI 700 + urea had 13 pseudothecia, and Latron
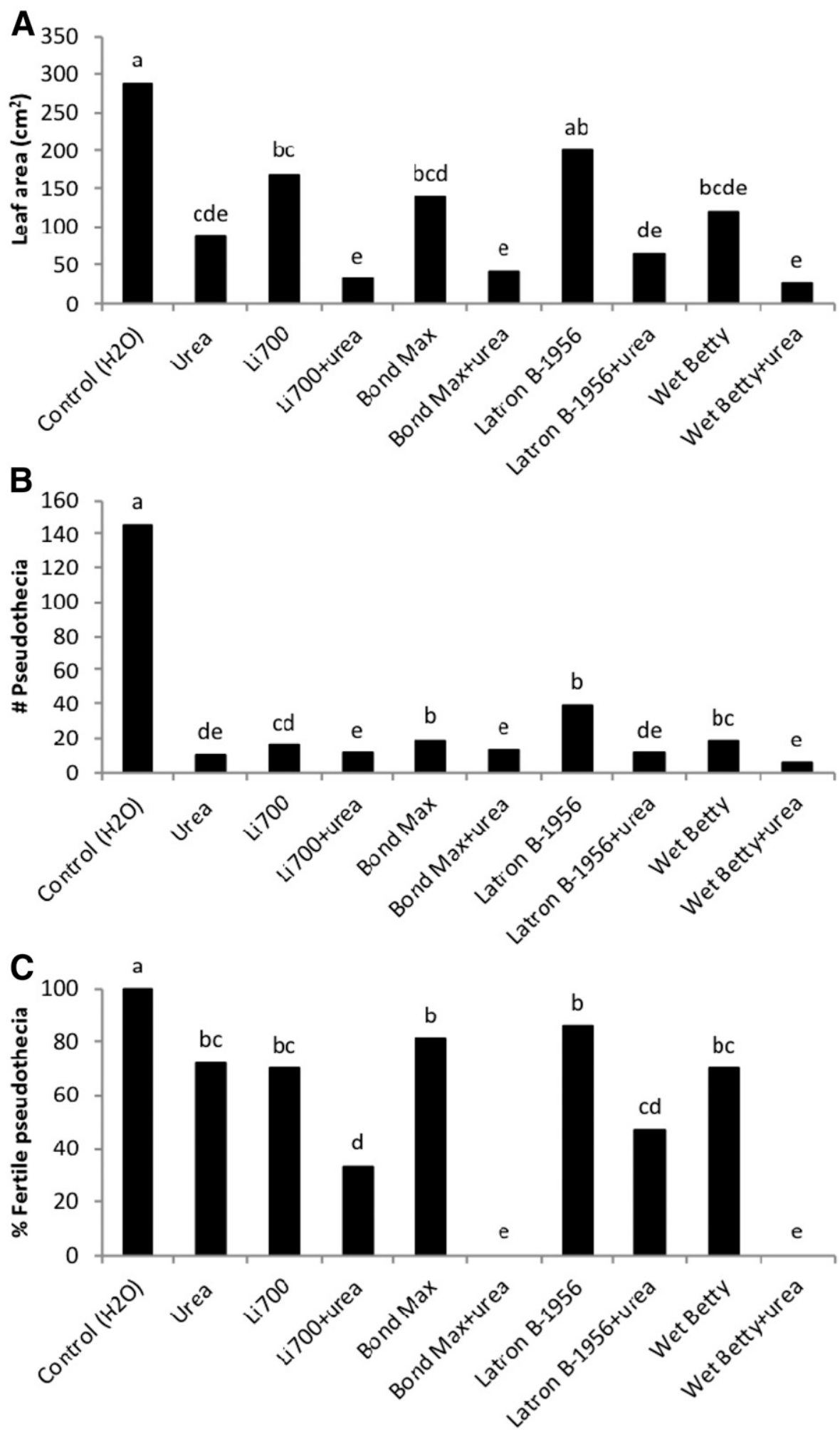

Fig. 2. Effect of adjuvants on leaf area of overwintered scab-infected McIntosh leaves (A), Venturia inaequalis pseudothecia present in sampled leaves (B), and percent fertile pseudothecia on scab-infected McIntosh leaves (C) overwintered at Meigs Farm, at the Throckmorton Purdue Agricultural Center in Lafayette, IN, 2014. Mean values followed by the same letter are not significantly different according to an analysis of variance and Fisher's protected LSD $(P<0.05)$. 
B-1956 + urea had 15, a significant reduction from urea alone. OWB + urea performed significantly better than all other treatments and decreased the number of pseudothecia to 3 (Fig. 3C). For Gala, the nontreated leaves had an average of 210 pseudothecia in the 2015 trial; treatment with urea alone reduced that to an average of 77 pseudothecia. Only Bond Max was comparable to urea in reduction of number of pseudothecia (Fig. 3D). For both cultivars, urea when combined with LI 700 had an average of 27 pseudothecia, treatment with Bond Max + urea had an average of 22 pseudothecia, and treatment with $\mathrm{OWB}+$ urea had an average of 13 pseudothecia, further decreasing the percentage of pseudothecia greater than the urea control (Fig. $3 \mathrm{C}$ and D). In the 2015 trial, urea-treated McIntosh leaves resulted in a reduction of fertile perithecia to $21.5 \%$; the addition of LI 700 , Latron B-1956, and OWB to urea reduced the percentage of fertile

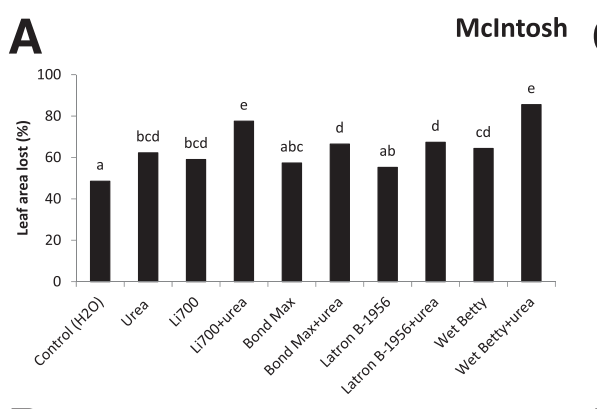

B

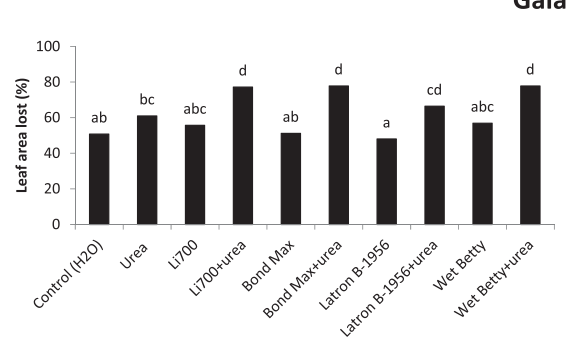

C

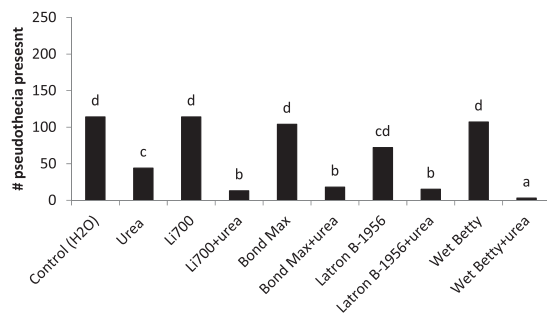

Gala

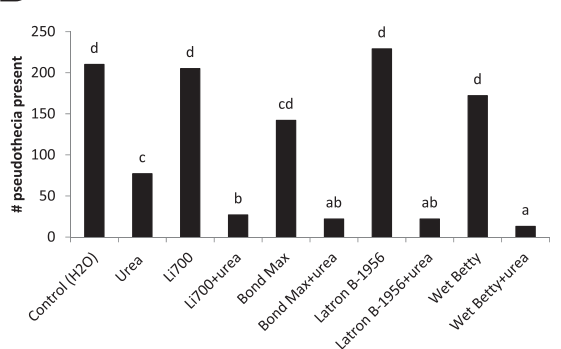

$\mathbf{E}$

McIntosh

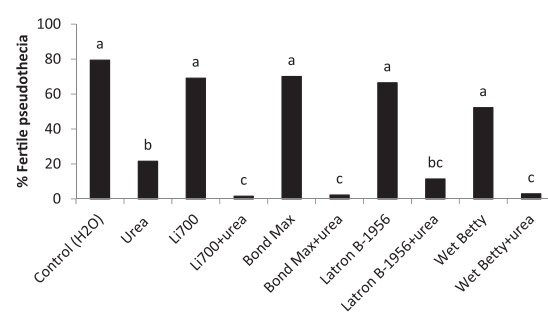

$\mathbf{F}$

Gala

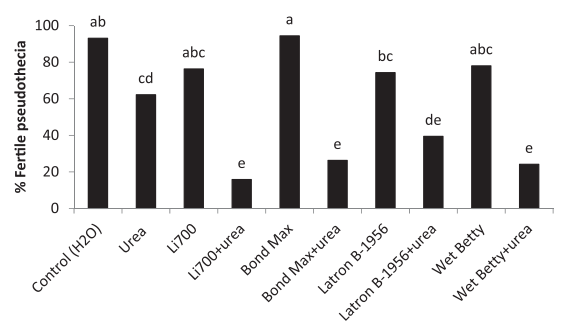

Fig. 3. Effect of adjuvants with and without urea on decomposition of overwintered scab-infected Mclntosh leaves (A) and scab-infected Gala leaves (B). Effect of adjuvants with and without urea on the number of Venturia inaequalis pseudothecia present in sampled scab-infected McIntosh leaves (C) and scab-infected Gala leaves (D). Effect of adjuvants with and without urea the percent of fertile pseudothecia on scab-infected Mclntosh leaves (E) and scab-infected Gala leaves (F) overwintered at Meigs Farm, Throckmorton Purdue Agricultural Center in Lafayette, IN, 2015. Mean values followed by the same letter are not significantly different according to an analysis of variance and Fisher's protected LSD $(P<0.05)$.

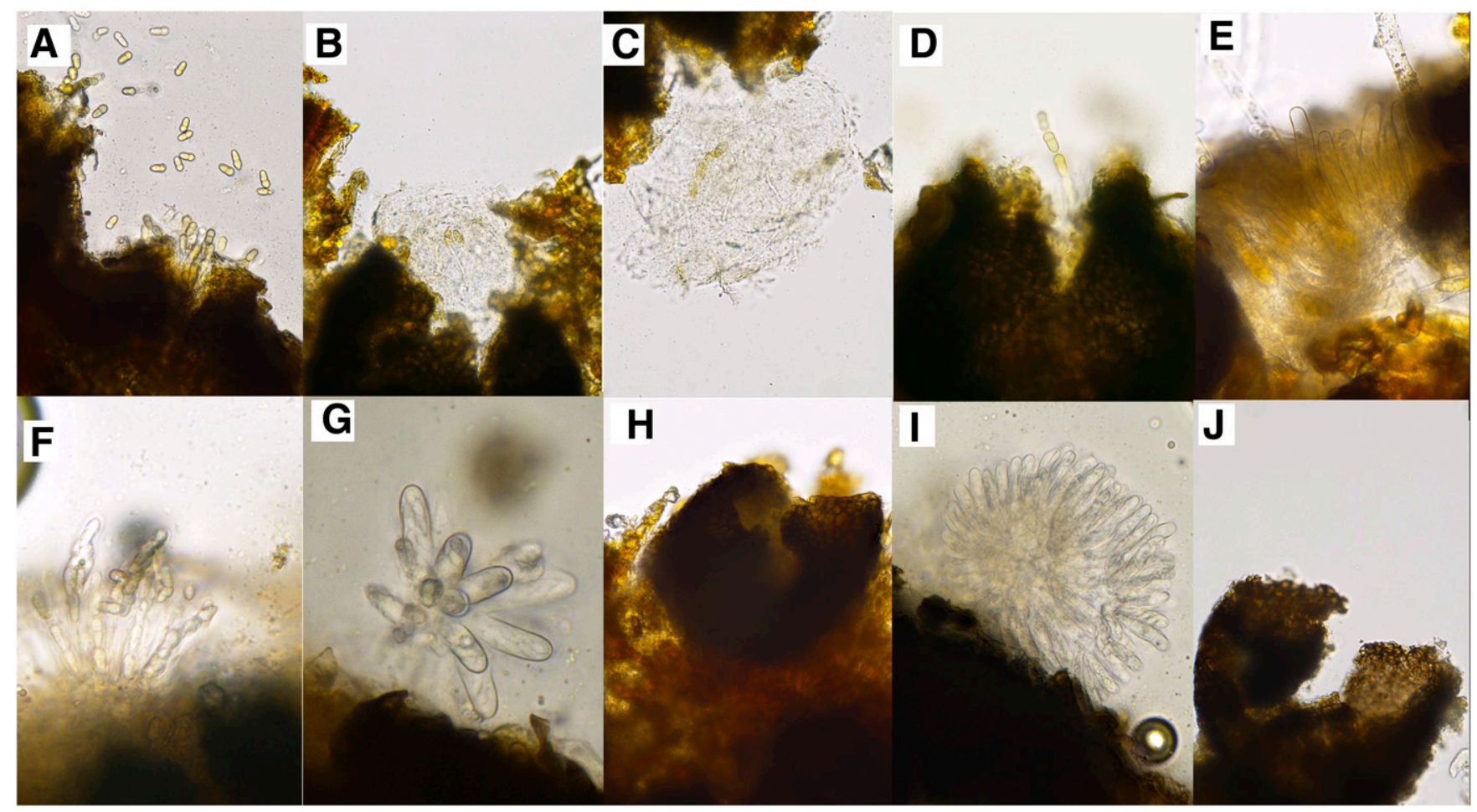

Fig. 4. Micrographs showing the development of the pseudothecia and ascospores of the fungus Venturia inaequalis in response to various adjuvant and urea treatments in 2014 Treatments: A, water; B, LI 700; C, Bond Max; D, Latron B-1956; E, Organic Wet Betty (OWB); F, urea; G, LI 700 + urea; H, Bond Max + urea; I, Latron B-1956 + urea; and J, OWB + urea. 
pseudothecia to less than 3\% (Fig. 3E). That same year, on Gala, urea reduced the number of fertile pseudothecia from an average of 93 to $62 \%$, whereas LI $700+$ urea reduced the percentage even further, to just under 16\% (Fig. 3F).

\section{Discussion}

The results from this 2-year study demonstrate that select adjuvants have the potential to hasten urea-driven leaf decomposition and reduce $V$. inaequalis inoculum, and that an organic surfactant can perform the same level of leaf decomposition as urea. The combination of OWB or LI 700 combined with urea significantly increased leaf decomposition and reduced the number and fertility of pseudothecia. Leaf decomposition differed slightly between apple cultivars, which may be owing to structural differences previously noted among apple cultivars (Picket and Kenworthy 1939).

As penetrants, the adjuvants OWB and LI 700 induce the movement of chemicals (in this case, urea) into plant tissue by lowering surface tension (Hazen 2000). Increasing nitrogen content in the leaves drives leaf decomposition (Beresford et al. 2000; Sutton et al. 2000) and inhibits pseudothecia development (Ross and Bremner 1971). It was shown by Leece and Dirou (1977) that an organosilicone surfactant with penetrant qualities increased the penetration of urea into leaves, which resulted in a $15 \%$ higher nitrogen content in leaves compared with adjuvants without penetrant qualities.

Temperature may have played a role in differentiating adjuvant effects on urea-driven leaf litter decomposition and inoculum reduction. For both years of this study, temperatures fell below $0^{\circ} \mathrm{C}$ within 3 weeks of initiation of the field tests. Urea treatments are ineffective if the ground freezes too soon after application (Mac an tSaoir et al. 2010; Rosenberger 1996; Sutton et al. 2000), reducing leaf litter decomposition and the activity of microbial populations that are antagonistic to $V$. inaequalis (Ciecierski et al. 1995). We suggest that the penetrant adjuvants LI 700 and OWB may have increased the uptake of urea and maximized the treatment efficacy before the ground froze, improving the efficacy of the urea treatment.

We found that that adjuvants, including Organic Materials Review Institute-approved products, were comparable to urea alone in reducing leaf litter and pseudothecia development. Burchill and Swait (1977) found similar results using anionic, ionic, and cationic surfactants to reduce $V$. inaequalis ascospore dose and found that inoculum reduction was owing to increases in leaf litter decomposition (Burchill and Swait 1977). More information regarding the mechanism by which adjuvants do this is needed to better understand these results. Among other adjuvants, OWB was comparable to urea alone in both years. In fact, in 2015, OWB alone decomposed McIntosh and Gala leaf litter to a greater extent than urea (Fig. 3A). Because OWB is an organic adjuvant, these results suggest that this adjuvant could be an acceptable alternative to urea applications in organic orchards and contribute to disease management and sanitation in organic orchards. Previous observations found yucca, a plant extract and the active ingredient in OWB, impacted stroma formation of $V$. inaequalis in leaves (Bengtsson et al. 2009). Because pseudothecia eventually develop from stroma (MacHardy et al. 2001), this could explain why OWB had a lesser effect on pseudothecia reduction in comparison with leaf litter decomposition. The greater effect on leaf litter reduction could also be owing to the organic plant material present in OWB promoting microorganism populations in the soil that decompose leaf litter. However, more research into this method is needed to better understand the benefits of using OWB.

In summary, the addition of certain adjuvants, such as OWB or LI 700 , to urea applied to apple leaves reduced the initial inoculum of $V$. inaequalis, which could potentially delay an apple scab epidemic (Gadoury and MacHardy 1986). A delay of a scab epidemic may have several benefits to apple disease management: first, by postponing the initial infection past the point when apples and leaves are most susceptible to $V$. inaequalis (Rosenberger and Cox 2012), and second, by saving fungicide sprays (Gadoury and MacHardy 1986; MacHardy et al. 1993). Delaying infection past the point of high susceptibility would decrease primary and consequently secondary infections. This would decrease disease incidence during the growing season and potentially reduce fungicides needed for adequate scab management throughout the summer (Rosenberger and Cox 2012).

Growers with poor disease control the previous year typically need to begin fungicide applications earlier and use higher rates of fungicides throughout the season (Rosenberger and Cox 2012). If these growers rely on captan for scab management during the season, they may run the risk of exceeding the 10 applications at a $4.5 \mathrm{~kg} / \mathrm{ha}$ rate per season restriction that is set on the captan label (Abbott and Beckerman 2018). Therefore, the incorporation of select adjuvants with urea could decrease the management problems associated with high-inoculum orchards by postponing the initial infection of $V$. inaequalis and reducing the primary and consequently secondary inoculum. The identification of an organic adjuvant to reduce overwintering inoculum in organic orchards provides a new tool for organic growers. In both organic and conventional orchards, the use of adjuvants with and without urea can reduce disease pressure and decrease the need for frequent applications of high rates of fungicides.

\section{Acknowledgments}

The authors acknowledge Tristand Tucker for his assistance on this project and George Sundin for critical review of this manuscript.

\section{Literature Cited}

Abbott, C., and Beckerman, J. 2018. Incorporating adjuvants with captan to manage common apple diseases. Plant Dis. 102:231-236.

American Society for Testing and Materials (ASTM). 1999. Standard terminology relating to agricultural tank mix adjuvants. Annual Book of ASTM Standards. Ed 1519-95. 11(05):905-906.

Beckerman, J. 2008. Using organic fungicides. Disease Management Strategies, Purdue Extension BP-69-W. https://www.extension.purdue.edu/extmedia/bp/ bp-69-w.pdf

Beckerman, J. L., Sundin, G. W., and Rosenberger, D. A. 2015. Do some IPM concepts contribute to the development of fungicide resistance? Lessons learned from the apple scab pathosystem in the United States. Pest Manag. Sci. 71:331-342.

Bengtsson, M., Wulff, E., Lyngs Jørgensen, H. J., Pham, A., Lübeck, M., and Hockenhull, J. 2009. Comparative studies on the effects of yucca extract and acibenzolar-S-methyl (ASM) on inhibition of Venturia inaequalis in apple leaves. Eur. J. Plant Pathol. 124:187-198.

Beresford, R. M., Horner, I. J., and Wood, P. N. 2000. Autumn-applied urea and other compounds to suppress Venturia inaequalis ascospore production. N. Z. Plant Prot. 53:387-392.

Burchill, R. T. 1968. Field and laboratory studies of the effect of urea on ascospore production of Venturia inaequalis (Cke). Wint. Ann. Appl. Biol. 62:297-307.

Burchill, R. T., and Swait, A. A. J. 1977. Eradication of the perithecia stage of apple scab with surfactants. Ann. Appl. Biol. 87:229-231.

Chapman, K. S., Sundin, G. W., and Beckerman, J. L. 2011. Identification of resistance to multiple fungicides in field populations of Venturia inaequalis. Plant Dis. 95:921-926.

Ciecierski, W., Cimanowski, J., and Bielenin, A. 1995. Effect of urea application on ascospore production of Venturia inaequalis. Acta Hortic. 422:395-396.

Creemers, P., Vanmechelen, A., and Hauke, K. 2002. Sanitation practices to reduce apple scab inoculum in orchards. Sixth International IOBC/WPRS Workshop of Pome Fruit Diseases, Lindau, Germany, 31 August-05 September 2002.

Gadoury, D. M., and MacHardy, W. E. 1986. Forecasting ascospore dose of Venturia inaequalis in commercial apple orchards. Phytopathology 76:112-118.

Gent, D. H., Schwartz, H. F., and Nissen, S. J. 2003. Effect of commercial adjuvants on vegetable crop fungicide coverage, absorption, and efficacy. Plant Dis. 87:591-597.

Goldsworthy, M. C., Dunegan, J. C., and Wilson, R. A. 1949. Control of apple scab by ground and tree applications of eradicant fungicides. Plant Dis. Rep. 33: 312-318.

Gomez, C., Brun, L., Chauffour, D., and De Le Vallée, D. 2007. Effect of leaf litter management on scab development in an organic apple orchard. Agric. Ecosyst. Environ. 118:249-255.

Hazen, J. L. 2000. Adjuvants: Terminology, classification, and chemistry. Weed Technol. 14:773-784.

Holb, I. J., Heijne, B., Withagen, J. C. M., Gall, J. M., and Jerger, M. J. 2005. Analysis of summer epidemic progress of apple scab at different apple production systems in the Netherlands and Hungary. Phytopathology 95: $1001-1020$

Jamar, L. 2011. Innovative strategies for the control of apple scab (Venturia inaequalis [Cke.] Wint.) in organic apple production. Doctoral thesis. Agricultural Sciences and Biological Engineering, Universite de Liège, Belgium.

Jones, A. L., and Walker, R. J. 1976. Tolerance of Venturia inaequalis to dodine and benzimidazole fungicides in Michigan. Plant Dis. Rep. 60:40-44. 
Kadow, K. J., and Hopperstead, S. L. 1941. Ground sprays aid in control of apple scab. (Abstr.). Phytopathology 31:13.

Keitt, G. W. 1930. Fall applications of fungicides in relation to apple-scab control. (Abstr.). Phytopathology 20:122.

Köller, W., Parker, D. M., Turechek, W. W., Avila-Adame, C., and Cronshaw, K. 2004. A two-phase resistance response to Venturia inaequalis populations to the QoI fungicides kresoxim-methyl and trifloxystrobin. Plant Dis. 88:537-544.

Köller, W., Wilcox, W. F., Barnard, J., Jones, A. L., and Braun, P. G. 1997. Detection and quantification of resistance of Venturia inaequalis populations to sterile demethylation inhibitors. Phytopathology 87:184-190.

Leece, D. R., and Dirou, J. F. 1977. Organosilicone and alginate adjuvants evaluated in urea sprays foliar-applied to prune trees. Commun. Soil Sci. Plant Anal. 8:169-176.

Mac an tSaoir, S., Cooke, L. R, and Mc Cracken, A. R. 2010. The effects of leaf litter treatments, post-harvest urea and omission of early season fungicide sprays on overwintering of apple scab on Bramley's Seedling grown in a maritime environment. Irish J. Agric. Food Res. 49:55-66.

MacHardy, W. E., Gadoury, D. M., and Gessler, C. 2001. Parasitic and biological fitness of Venturia inaequalis: Relationship to disease management strategies. Plant Dis. 85:1036-1051.

MacHardy, W. E., Gadoury, D. M., and Rosenberger, D. A. 1993. Delaying the onset of fungicide programs for control of apple scab in orchards with low potential ascospore dose of Venturia inaequalis. Plant Dis. 77:372-375.

McKay, A. H., Hagerty, G. C., Follas, G. B., Moore, M. S., Christie, M. S., and Beresford, R. M. 2011. Succinate dehydrogenase inhibitor (SDHI) fungicide resistance prevention strategy. N. Z. Plant Prot. 64:119-124.

Meszka, B., and Bielenin, A. 2006. Non-chemical possibilities for control of apple fungal diseases. Phytopathol. Pol. 39:63-70.

Percich, J. A., and Nickelson, L. J. 1982. Evaluation of several fungicides and adjuvant materials for control of brown spot of wild rice. Plant Dis. 66:1001-1003.

Picket, W. F., and Kenworthy, A. L. 1939. The relationship between structure, chlorophyll content and photosynthesis in apple leaves. Proc. Am. Soc. Hortic. Sci. 37:371-373.
Rosenberger, D. 1996. A correction and a caution on postharvest urea sprays to control scab. Online publication. Scaffolds Fruit J. 5. http://www.scaffolds. entomology.cornell.edu/1996/scaffolds_0923.html

Rosenberger, D. 2003. Factors limiting IPM-compatibility of new disease control tactics for apples in eastern United States. Online publication. Plant Health Prog. 4.

Rosenberger, D., and Cox, K. 2012. Managing apple scab in high inoculum orchards. Fruit Notes. 77:16-19.

Ross, R. G., and Bremner, F. D. 1971. Effect of ammonium nitrogen and amino acids on perithecial formation of Venturia inaequalis. Can. J. Plant Sci. 51: 29-33.

Schneider, C. A., Rasband, W. S., and Eliceiri, K. W. 2012. NIH Image to ImageJ: 25 years of image analysis. Nat. Methods 9:671-675.

Schupp, J., Cheng, L., Stiles, W. C., Stover, E., and Iungerman, K. 2001. Mineral nutrition as a factor in cold tolerance of apple trees. N. Y. Fruit Q. 9:17-20.

Steurbaut, W. 1993. Adjuvants for use with foliar fungicides. Pestic. Sci. 38:85-91

Sutton, D. K., MacHardy, W. E., and Lord, W. G. 2000. Effects of shredding or treating apple leaf litter with urea on ascospore dose of Venturia inaequalis and disease buildup. Plant Dis. 84:1319-1326.

Sutton, T. B. 1990. Apple scab. Pages 6-8 in: Compendium of Apple and Pear Diseases. A. L. Jones and H.S. Aldwinckle, eds. American Phytopathological Society, St. Paul, MN.

Szkolnik, M., and Gilpatrick, J. D. 1969. Apparent resistance of Venturia inaequalis to dodine in New York apple orchards. Plant Dis. Rep. 53:861-864

Thompson, W. M., Nissen, S. J., and Master, R. A. 1996. Adjuvant effects on imazethapyr, 2,4-D and picloram absorption by leafy spurge (Euphorbia esula). Weed Sci. 44:469-475.

Vincent, C., Rancourt, B., and Carisse, O. 2004. Apple leaf shredding as a nonchemical tool to manage apple scab and spotted tentiform leafminer. Agric. Ecosyst. Environ. 104:595-604.

Wood, P. N., and Beresford, R. M. 2000. Avoiding apple bud damage from autumn-applied urea for black spot (Venturia inaequalis) control. N. Z. Plan Prot. 53:382-386. 